\title{
Penerapan Metode Snowball Throwing Dalam Pembelajaran Baahasa Inggris Untuk Meningkatkan Penguasaan Kosa Kata Dan Kemampuan Psikomotorik Siswa Sd Islam Terpadu Kota Sorong
}

\author{
Syams Kusumaningrum \\ Irna Ganda Setyawati \\ STKIP Muhammadiyah Sorong \\ Email: syams.bing@gmail.com
}

\begin{abstract}
Abstrak: Snowball Throwing merupakan metode pembelajaran menggunakan media kertas bertuliskan suatu kata yang digulung berbentuk bola. Metode ini pada umumnya digunakan dalam pembelajaran Bahasa Inggris. Penelitian ini bertujuan untuk menguji pengaruh metode snowball throwing terhadap penguasaan kosakata dan kemampuan psikomotorik pada pembelajaran Bahasa Inggris siswa SD Islam Terpadu Kota Sorong. Desain pada penelitian ini adalah eksperimen kuasi, yaitu Randomized Pre-Post Test Control Group Design. Subjek penelitian terdiri dari 2 kelompok eksperimen dan kontrol yang masing-masing berjumlah 27 siswa. Terdapat dua instrumen dalam penelitian ini yaitu tes kosakata Bahasa Inggris dan tes kemampuan psikomotorik. Penelitian ini diuji menggunakan teknik non-parametrik, yaitu Mann Whitney U Test dan Wilcoxon Signed Ranks Test. Berdasarkan uji hipotesis 2 sampel berpasangan ditemukan bahwa ada nilai signifikansi penguasaan kosakata $(p=0,000)$ dan psikomotor $(\mathrm{p}=0,016)$ pada kelompok eksperimen lebih rendah dari batas kritis penelitian 0,05, sehingga dapat disimpulkan bahwa metode snowball throwing berpengaruh signifikan terhadap kemampuan kosakata Bahasa Inggris dan psikomotor siswa kelas 1 SD Islam Terpadu Kota Sorong.
\end{abstract}

Kata Kunci: snowball throwing, penguasaan kosakata bahasa Inggris, kemampuan psikomotorik.

\section{Pendahuluan}

Penguasaan bahasa Inggris sangat diperlukan di masa sekarang ini, tidak hanya bagi orang dewasa namun juga bagi siswa sekolah. Bahasa Inggris di Sekolah dipelajari sebagai persiapan untuk mengenal lebih jauh dunia luar. Dalam pembelajaran bahasa Inggris terdapat banyak aspek yang perlu diperhatikan, seperti penguasaan grammar, kosakata, pengucapan dan lain sebagainya (Burn, dkk, 2015). Sebagai salah satu aspek pembelajaran bahasa Inggris yang utama, penguasaan kota kata menjadi dasar untuk dapat menguasai dan berkomunikasi dalam bahasa Inggris (Alderson \& Bachman, 2000).

Penguasaan kosakata bahasa Inggris pada masa kanak-kanak sangatlah penting. Pada usia 2 sampai 7 tahun, anak berada pada tahap perkembangan kognisi pra-operasional (Piaget, 1964). Tahap pra-operasional ditandai dengan berkembangnya pemikiran intuitif dan fungsi semiotik atau simbol (Padmanabha, 2018). Hal ini berarti metodemetode pembelajaran yang aktif dan bersifat konkrit seperti permainan dan drama sangatlah efektif untuk diterapkan pada usia ini (Kwan \& Wong, 2015; Gilman, 2012). Sesuai dengan teori perkembangan dan data yang dihimpun oleh NAEYC (National Association For The Education Of Young Children) tahun 2006 yang menyatakan bahwa anak-anak pada tahap usia taman kanak-kanak lebih cocok diperlihatkan perilaku konkrit dan kebiasaan-kebiasaan belajar yang menyenangkan dan bersifat aktif (Khanifatul, 2014).

Pendidikan pada masa awal anak-anak adalah suatu permulaan awal untuk memastikan anak-anak dapat berkembang optimal sesuai tahap perkembangannya. Pada 
tahap ini anak dengan cepat mampu menyerap suatu norma dan nilai melalui analogianalogi ringan yang diaosiasikan dengan suatu tokoh atau permainan tertentu (Berger \& McLanahan, 2015)

Metode pembelajaran melalui permainan selain menyenangkan juga dapat melatih kemampuan psikomotorik anak. Pada usia 4 tahun, anak-anak harusnya terlibat aktif dalam kegiatan-kegiatan yang melibatkan motorik kasar dan lebih berani mengambil resiko dalam sebuah permainan (Masek \& Masduki, 2017). Faktanya berdasarkan hasil penelitian para ahli psikologi, pada usia 3 sampai 7 tahun anak-anak memiliki tingkat aktivitas tertinggi dari seluruh masa kehidupannya (Santrock, 2003).

Pada tahap ini koordinasi motorik anak berkembang dengan cepat sehingga membutuhkan rangsangan agar anak dapat berkembang dengan optimal. Perkembangan psikomotorik sejalan dengan perkembangan kognitif, artinya apabila kemampuan psikomotorik anak dapat berkembang secara optimal maka kemampuan kognitifnya pun demikian. Stimulasi-stimulasi melalui bentuk aktivitas fisik diharapkan dapat mendukung proses belajar anak usia praoperasional. Di sisi lain, anak pada rentang usia 4-7 tahun memiliki minat yang tinggi terhadap penguasaan katakata baru beserta artinya. Anak mulai tertarik ketika komunikasi dengan teman sebayanya mulai intensif. Ketertarikan terhadap penguasaan kosakata baru ini dapat difasilitasi melalui bentuk-bentuk pembelajaran aktif seperti melalui permainan individual maupun kelompok (LeBarton, dkk, 2015).

Dalam kaitannya dengan pengajaran penguasaan kosakata pada anak-anak, dibutuhkan persiapan yang lebih matang dan terperinci (Stein, 2014). Guru terlebih dahulu harus mengetahui jenis kosakata yang dibutuhkan oleh anak-anak untuk kemudian diajarkan. Pemilihan kosakata yang akan diajarkan juga harus disesuaikan dengan tingkat pemahaman dan pengalaman mereka (Stein, 2014; McCartern, 2007). Pada masa kanak-kanak, akan lebih baik jika diajarkan bentuk kosakata sederhana yang berkaitan dengan objek atau benda yang familiar bagi mereka. Hal ini ditujukan agar anak tidak hanya mengetahui nama dari benda atau objek yang dimaksud namun juga dapat memahami konsep serta mampu menjelaskan fungsi dari benda tersebut (Duff, dkk, 2015). Dengan kata lain pengenalan kosakata yang berkaitan dengan kata benda perlu untuk diajarkan kepada siswa karena berkaitan dengan tahap perkembangan kognitif praopersaional mereka (Scott \& Yteberg, 2002).

Snowball throwing merupakan model pembelajaran yang membagi murid dalam beberapa kelompok. Satu kelompok dapat terdiri dari 5 hingga 7 siswa. Masing-masing anggota kelompok membuat bola dari kertas berisi kosakata bahasa Inggris yang sudah dipelajari sebagai bahan dalam pembelajaran (Susanty, 2016). Bola-bola kosata kata yang telah terkumpulkan kemudian diacak dan seorang siswa akan mengambil salah satu bola secara acak dan melemparkan kearah teman-temannya. Siswa yang menangkap bola tersebut kemudian diminta membuka dan membaca kosakata yang ada di dalam bola tersebut dalam bahasa Inggris, lalu menjelaskan secara singkat makna kata tersebut dalam bahasa Indonesia. Permainan ini diharapkan dapat menstimulasi penguasaan kosakata dan mengasah keterampilan psikomotorik siswa sesuai dengan tahap awal masa perkembangannya (Pane \& Ernidawati, 2014).

Snowball throwing merupakan metode pembelajaran yang menggunakan bola pertanyaan dari kertas yang digulung bulat berbentuk bola kemudian dilemparkan secara bergiliran di antara sesama anggota kelompok (Isjoni, 2010). Pertanyaan dibuat oleh siswa bersumber pada materi yang diajarkan dengan tujuan merangsang siswa mengemukakan pertanyaan sesuai dengan topik yang sedang dibicarakan dalam pembelajaran. Disamping membuat pertanyaan, siswa juga dilatih untuk menjawab pertanyaan yang diajukan oleh temannya dengan baik (McCarten, 2007; Hiebert \& Kamil, 2005).

Metode snowball throwing mengajak siswa untuk lebih aktif dalam belajar. Hal ini sesuai dengan tahap perkembangan anak usia 4-7 tahun (Sari, dkk, 2018). Sesuai dengan tahap perkembangannya, pada usia ini anak lebih aktif dalam mengembangkan kemampuan psikomotoriknya lebih dari usia-usia yang lain. Metode snowball throwing diharapkan dapat membantu siswa dalam mengembangkan kemampuan psikomotorik yang dimiliki, serta menambah penguasaan kosakata bahasa Inggris mereka.

Bersadarkan hasil survei awal peneliti di SD Islam Terpadu Kota Sorong, pembelajaran bahasa Inggris yang saat ini sedang berjalan masih bersifat konvensional dengan sistem hafalan. Hal ini 
membuat anak-anak kurang begitu tertarik dan cenderung merasa kesulitan dalam mempelajari kosakata bahasa Inggris. Dengan demikian, banyak siswa yang terlihat kurang aktif dalam proses pembelajaran. Mereka cenderung mengantuk atau sibuk dengan hal-hal lain diluar pembelajaran seperti bermain dengan temannya ataupun bermain dengan barang-barang miliknya sendiri. Hasil pembelajaran siswa pun cenderung rendah. Hasil wawancara terhadap salah seorang siswa menunjukkan ia kurang tertarik dengan pembelajaran bahasa Inggris dan cenderung mudah lupa dengan materi yang sudah diajarkan sebelumnya. Hipotesis dalam penelitian ini adalah.

\begin{tabular}{|c|c|}
\hline $\mathrm{H}_{0} \mathrm{~A}$ & $\begin{array}{l}\text { Tidak ada pengaruh metode } \\
\text { pembelajaran Snowball Throwing } \\
\text { terhadap peningkatan penguasaan } \\
\text { kosakata siswa SD Islam Terpadu } \\
\text { Kota Sorong }\end{array}$ \\
\hline $\mathrm{H}_{0} \mathrm{~B}$ & $\begin{array}{l}\text { Tidak ada pengaruh metode } \\
\text { pembelajaran Snowball Throwing } \\
\text { terhadap peningkatan kemampuan } \\
\text { psikomotor siswa SD Islam Terpadu } \\
\text { Kota Sorong }\end{array}$ \\
\hline $\mathrm{H}_{1} \mathrm{~A}$ & 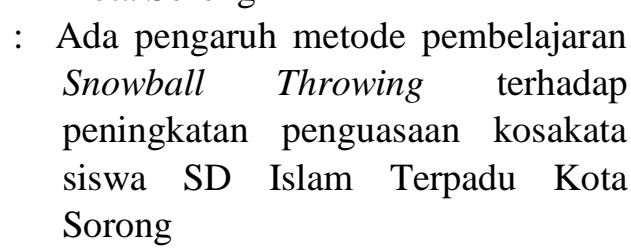 \\
\hline $\mathrm{H}_{1} \mathrm{~B}$ & $\begin{array}{l}\text { Ada pengaruh metode pembelajaran } \\
\text { Snowball Throwing terhadap } \\
\text { peningkatan kemampuan } \\
\text { psikomotor siswa SD Islam Terpadu } \\
\text { Kota Sorong }\end{array}$ \\
\hline
\end{tabular}

\section{Metode Penelitian}

Penelitian ini adalah penelitian eksperimen dengan desain kuasi pre-posttest control group design (Shadish, Cook, \& Campbell, 2002) dengan cakupan populasi adalah siswa kelas 1 SD Islam Terpadu Kota Sorong yang terdiri atas laki-laki maupun perempuan. Teknik sampling dalam penelitian ini adalah stratified random sampling yaitu cara pengambilan sampel dengan memperhatikan strata (tingkatan) dalam populasi. Strata yang dimaksudkan dalam penelitian ini adalah pemilihan kategori berdasarkan kelas (kelompok) siswa tersebut. Randomisasi dilakukan untuk memilih kategori kelas yang akan dipilih sebagai kelompok eksperimen dan kontrol. Penelitian akan dilakukan di SD Islam Terpadu Kota Sorong sesuai waktu yang telah ditetapkan.

Penelitian ini dilakukan diawali dengan survey awal untuk meninjau model pembelajaran yang diterapkan dan diperoleh siswa selama ini. Kemudian, peneliti melakukan randomisasi terhadap kategori kelas yang akan dijadikan kelompok eksperimen dan kontrol. Setelah itu, peneliti melakukan screening sekaligus berguna sebagai data skor pretest sampel terpilih. Setelah dilakukan pretest, kemudian perlakuan diberikan kepada kelompok eksperimen yaitu dengan menerapkan metode snowball throwing, sedangkan kelompok kontrol tidak diberikan perlakuan. Setelah perlakukan diberikan, kemudian kedua kelompok diberikan posttest untuk melihat perubahan yang terjadi pada masing-masing kelompok eksperimen dan kontrol.

Dalam penelitian ini, peneliti menggunakan metode observasi, wawancara dan dokumentasi. Disamping itu sebagai instrumen, peneliti menggunakan lembar evaluasi hasil belajar berbentuk soal dengan konsep fill in the blank serta latihan psikomotorik berbentuk simulasi permainan. Instrumen penelitian di uji validasi menggunakan secara profesional (professional judgement).

Uji prasyarat dalam penelitian ini yaitu menggunakan uji normalitas Shapiro Wilk, dan uji homogenitas menggunakan levene test. Pengujian hipotesis dalam penelitian ini menggunakan 
teknik statistik non-parametrik yaitu Mann Whitney Test untuk membandingkan kondisi antara kelompok eksperimen dan kontrol, serta Wilcoxon Signed Ranks Test untuk menguji perubahan internal pada masing-masing kelompok eksperimen dan kontrol.

\section{Hasil dan Pembahasan}

\subsection{Hasil Penelitian}

Dalam penelitian ini terdapat dua jenis instrumen yang divalidasi berdasarkan penilaian ahli. Yang pertama adalah instrumen soal dengan konsep fill in the blank yang digunakan pada saat pretest dan post-test. Masing-masing soal terdiri dari 15 nomor dengan komposisi 5 soal untuk number, 5 soal untuk materi fruit dan 5 soal untuk materi colour. Ketiga materi tersebut merupakan materi pelajaran Bahasa Inggris yang diajarkan pada siswa kelas 1 SD di semester 2 (genap). Soal-soal yang dibuat oleh peneliti kemudian dikonsultasikan kepada profesional yang sekaligus merupakan praktisi pendidikan untuk memastikan kesesuaian soal yang telah dibuat dengan level atau kemampuan siswa kelas $1 \mathrm{SD}$.

Selain instrumen soal, instrumen lain yang juga divalidasi berdasarkan penilaian ahli adalah instrumen penilaian psikomotorik. Berbeda dengan instrumen soal yang ditujukan untuk menilai kemampuan kosakata Bahasa Inggris, instrumen penilaian psikomotorik ditujukan untuk menilai kemampuan psikomotorik dalam kaitannya dengan ketepatan memasukkan bola kedalam kotak yang telah disediakan. Dalam membuat instrumen psikomotorik peneliti melakukan konsultasi dengan profesional yang juga merupakan seorang psikolog yaitu Aswendo Dwitantyanov, M.Psi., Psikolog., untuk memvalidasi indikator penilaian yang telah dibuat oleh peneliti.

Eksperimen metode pembelajaran snowball throwing dilakukan setelah pretest diberikan. Eksperimen dilakukan dalam 3 tahap dan kemudian diakhiri dengan posttest. Pada sesi pre-test terdapat dua kegiatan yang dilakukan oleh siswa, yaitu mengerjakan soal yang berisi materi kosakata, kemudian setelah selesai mengerjakan soal tersebut, satu persatu siswa diminta untuk memasukkan bola ke dalam kotak yang telah disediakan dengan cara melempar. Kegiatan ini pula yang akan dilakukan pada sesi post-test. Setelah melakukan pre-test, tahapan selanjutnya adalah pemberian perlakuan pada kelompok eksperimen. Pemberian perlakuan dilakukan dalam 3 pertemuan (sesi) melalui proses pembelajaran di kelas.

Secara teknis tahapan pembelajaran dalam ke tiga sesi perlakuan terdiri dari tiga tahapan yaitu pendalaman materi, simulasi permainan dengan menggunakan metode snowball throwing dan refleksi. Adapun yang mebedakan adalah materi kosakata bahasa Inggris yang akan diajarkan dalam tiap pertemuan. Pada petemuan pertama siswa diberikan materi number (angka) yang terdiri dari angka 1 sampai dengan 10, sedangkan di pertemuan ke dua siswa diajarkan materi fruit yang terdiri dari sepuluh jenis buah seperti apple, banana, mango, papaya, orange, watermelon, avocado, grape, durian dan coconut, terakhir pada persetmuan ke tiga siswa perkenalkan materi colour yang terdiri dari sepuluh macam warna seperti black, purple, orange, green, red, brown, yellow, white, pink dan blue.

Berdasarkan hasil pretest ditemukan bahwa data homogen, namun tidak normal. Uji normalitas dilakukan dengan menggunakan pendekatan Shapiro Wilk dengan asumsi metode ini dapat digunakan pada jumlah subjek yang sedikit. Dari output Shapiro-Wilk di bawah ini terlihat bahwa asumsi signifikansi data pretest kosakata pada kelompok eksperimen adalah sebesar 0,016 dan pada kelompok kontrol adalah sebesar 0,011; sedangkan asumsi signifikansi data pretest psikomotorik pada kelompok eksperimen adalah sebesar 0,004 dan pada kelompok kontrol adalah sebesar 0,006. Dari keempat distribusi data pretest tersebut, nampak bahwa nilai signifikansi (p value) $<0,05$ (dengan taraf kepercayaan/ signifikansi 95\%).

Setelah melakukan uji normalitas maka langkah selanjutnya adalah melakukan uji homogenitas. Adapun dalam penelitian ini, peneliti menggunakan levene test yang mana menunjukkan bahwa data bersifat homogen. Berdasarkan hasil yang dipaparkan di atas, nilai uji levene test ditunjukkan pada baris based on mean, yaitu pada skor pretest penguasaan kosakata sebesar $0,996(>0,05)$ dan pada skor pretest psikomotorik sebesar $0,561(>0,05)$ yang berarti varians kedua kelompok yaitu eksperimen dan kontrol adalah sama atau homogen. Kesamaan kedua varians 
tersebut dikarenakan kemampuan siswa baik kelas IA maupun Kelas IB tidak jauh berbeda, hal ini dapat diamati berdasarkan nilai harian dan hasil pretest itu sendiri secara kualitatif dan kuantitatif.

Berdasarkan hasil analisis statistik Ranks data kedua kelompok terlihat bahwa rata-rata peringkat kelompok eksperimen pada post-test penguasaan kosakata lebih besar daripada kelompok kontrol $\left(\mathrm{K}_{\mathrm{e}}=39,74>\mathrm{K}_{\mathrm{k}}=15,26\right)$. Begitu pula, pada hasil tes psikomotorik $\left(\mathrm{K}_{\mathrm{e}}=31,30>\mathrm{K}_{\mathrm{k}}=23,70\right)$. Sedangkan pada data pretest penguasaan kosakata cenderung sama antara kelompok eksperimen dan kontrol $\left(\mathrm{K}_{\mathrm{e}}=27,81\right.$ dan $\left.\mathrm{K}_{\mathrm{k}}=27,19\right)$, begitu pula pada pretest psikomotorik $\left(\mathrm{K}_{\mathrm{e}}=29,31\right.$ dan $\mathrm{K}_{\mathrm{k}}=$ $25,69)$. Hal ini menunjukkan rata-rata peringkat kelompok eksperimen pada post-test penguasaan kosakata lebih besar daripada kelompok kontrol. Begitu pula, pada hasil tes psikomotorik.

\section{Tabel 1. Ranks}

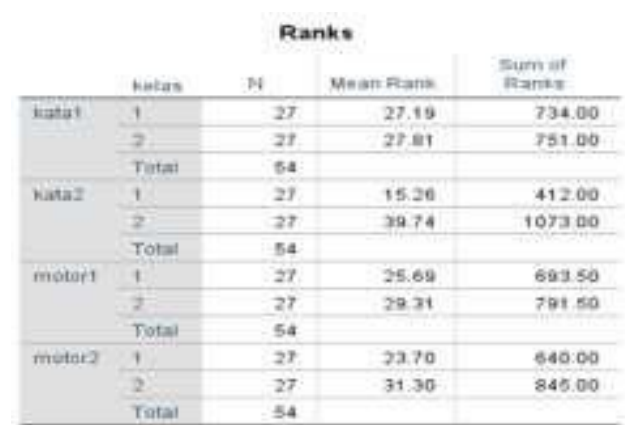

Berdasarkan tabel hasil posttest kosakata pada kelompok eksperimen ditemukan bahwa dari 27 siswa terdapat 1 orang yang tidak mengalami peningkatan atau tetap (subjek nomor 21). Hal ini dapat disebabkan oleh kondisi kesehatan subjek eksperimen tersebut pada pertemuan/ sesi kedua mengalami penurunan kondisi kesehatan. Subjek saat di probing mengatakan sedang mengalami flu dan meriang, sehingga diasumsikan tidak dapat mengikuti proses pembelajaran dengan optimal. Sedangkan, sisanya yaitu sebanyak 26 orang mengalami kenaikan. Dua diantaranya bahkan memiliki skor yang meningkat drastis sebanyak 10 poin (subjek nomor 1 dan 19).

Berbeda dengan hasil posttest kosakata kelompok eksperiman yang mengalami kenaikan, pada hasil posttest kosakata kelompok kontrol terlihat tidak mengalami peningkatan secara signifikan. Berdasarkan sebaran data, diketahui bahwa sebanyak 16 subjek mengalami penurunan nilai, yaitu subjek nomor 2, 4, 5, 6, 7, 8, 10, 15, 16, 18, 19, 21, 22, 25, 26, dan 27. Penurunan terendah terjadi beragam mulai dari 1 hingga maksimal 4 poin. Selebihnya sebanyak 6 subjek mengalami kestabilan skor, yaitu subjek nomor $9,11,13,14,17$, dan 20. Sebanyak 5 subjek mengalami peningkatan skor, yaitu pada subjek nomor 1, 3, 12, 23, dan 24. Peningkatan tertinggi terjadi sebanyak 3 poin terjadi pada subjek nomor 1 dan 3. Peningkatan skor kosakata yang terjadi pada kelompok kontrol ketika diuji secara statistik, terlihat bahwa hal tersebut bersifat tidak signifikan sehingga dapat dikatakan bahwa tidak terjadi peningkatan skor.

Pada sebaran data skor tes psikomotor terdapat 12 subjek yang mengalami peningkatan skor sebanyak 1 poin, 10 subjek memiliki kestabilan skor antara pretest dan posttest, dan 5 subjek mengalami penurunan skor sebanyak 1 poin. Peningkatan skor dapat dipengaruhi oleh faktor historis, yaitu subjek pada kelompok kontrol mengalami proses pembelajaran sosial dari kondisikondisi di luar penelitian yang tidak dapat dikontrol selama proses penelitian (variabel extranous). Peningkatan juga diasumsikan terjadi disebabkan adanya interaksi secara tidak langsung antara subjek pada kelompok eksperimen dan kontrol selama di sekolah maupun di luar sekolah. Kondisikondisi seperti ini, disadari oleh peneliti belum dapat dikontrol sehingga dimungkinkan mempengaruhi fluktuasi pada skor hasil pengukuran subjek.

Di sisi lain pada kelompok eksperimen terdapat 12 subjek yang mengalami peningkatan skor psikomotor maksimal sebanyak 2 poin, 12 subjek mengalami kestabilan skor, dan 3 subjek mengalami penurunan skor. Setelah dilakukan uji non parametrik Mann Whitney dengan meninjau besaran nilai $\mathrm{Z}$ terlihat bahwa perubahan-perubahan yang terjadi pada skor psikomotorik baik pada kelompok eksperimen maupun kontrol adalah tidak signifikan. Ratarata peningkatan skor tes psikomotor pada subjek kelompok eksperimen juga lebih banyak terjadi dibandingkan pada kelompok kontrol. Akan tetapi, untuk mengetahui apakah perbedaan tersebut signifikan atau tidak, 
maka peneliti melakukan analisis untuk menunjau besaran koefisien signifikansi ( $p$ value) dengan menggunakan pendekatan Mann Whitney U Test.

\section{Tabel 2. Mann Whitney U Test}

\begin{tabular}{|c|c|c|c|c|}
\hline \multicolumn{5}{|c|}{ Test Statistics $^{\mathrm{a}}$} \\
\hline & kata1 & kata 2 & motor 1 & motor 2 \\
\hline Mann-WhitnerU & 356.000 & 34.000 & 315.500 & 262.000 \\
\hline Wilcovon W & 734.000 & 412.000 & 693.500 & 640.000 \\
\hline 2 & -148 & -5.736 & .894 & $-1,945$ \\
\hline Asymp, Sig. (2.talled) & 882 & .000 & .372 & .052 \\
\hline
\end{tabular}

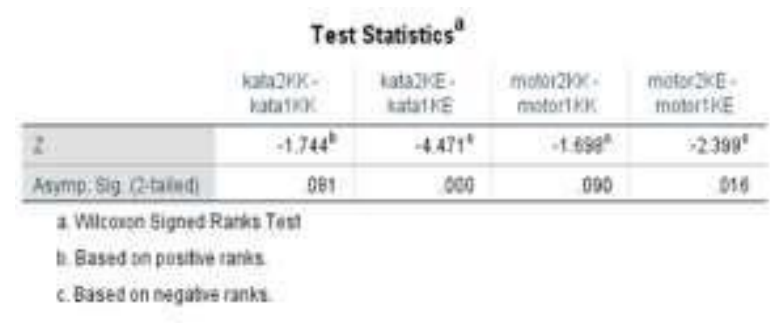

Berdasarkan hasil uji Mann Whitney U Test, terlihat bahwa nilai U pada skor posttest penguasaan kosakata adalah 34,000 dan skor posttest psikomotor adalah 262,000. Nilai W posttest penguasaan kosakata adalah sebesar 412,000 dan posttest psikomotor adalah sebesar 640,000. Apabila dikonversi kedalam nilai $\mathrm{Z}$ maka diperoleh besaran $\mathrm{Z}$ yaitu $-0,5736$ pada posttest penguasaan kosakata dan $-1,945$ pada posttest psikomotor. Nilai signifikansi ( $p$ value) pada uji hipotesis dua sisi adalah sebesar 0,000 untuk skor posttest penguasaan kosakata dan sebesar 0,052 untuk skor posttest psikomotor. Hal ini menunjukkan ada perbedaan bermakna antara kelompok eksperimen dan kontrol pada skor posttest penguasaan kosakata, namun tidak demikian pada skor posttest psikomotor. Kemudian, tahapan selanjutnya adalah menguji perubahan yang terjadi antara kondisi pretest dan posttest . Untuk itu, peneliti menggunakan Wilcoxon Signed Ranks Test yang termasuk uji 2 sampel berpasangan. Pada tahap ini akan dibandingkan beberapa kondisi/ situasi, yaitu:

a) Skor pretest penguasaan kosakata kelompok kontrol dibandingkan dengan skor posttest penguasaan kosakata kelompok kontrol

b) Skor pretest penguasaan kosakata kelompok eksperimen dibandingkan dengan skor posttest penguasaan kosakata kelompok eksperimen

c) Skor pretest psikomotor kelompok kontrol dibandingkan dengan skor posttest psikomotor kelompok kontrol

d) Skor pretest psikomotor kelompok eksperimen dibandingkan dengan skor posttest psikomotor kelompok eksperimen

Untuk itu, peneliti menggunakan

Wilcoxon Signed Ranks Test yang termasuk uji 2 sampel berpasangan. Berikut adalah hasil analisis datanya:

\subsection{Pembahasan}

Terjadi suatu hal unik pada skor psikomotor. Jika diperbandingkan antara skor posttest psikomotor kelompok eksperimen dan kelompok kontrol dengan menggunakan uji 2 sample independent Mann Whitney U Test $(\mathrm{p}=0,052)$, terlihat bahwa tidak ada perbedaan signifikan antara kelompok eksperimen dan kontrol. Sedangkan pada uji berpasangan Wilcoxon Signed Ranks Test, terlihat bahwa data posttest kelompok eksperimen berbeda signifikan dengan data pretest kelompok eksperimen $(\mathrm{p}=0,016)$. Hal ini menunjukkan bahwa perubahan yang terjadi pada kelompok eksperimen pada aspek psikomotor cukup signifikan. Namun dapat diilustrasikan bahwa perubahan pada aspek psikomotor cenderung rendah walaupun signifikan. 
Hal ini dapat diartikan bahwa peneliti menerima $\mathrm{H}_{1}$ dan menolak $\mathrm{H}_{0}$ pada pengukuran penguasaan kosakata dan psikomotor. Dengan demikian, penelitian ini menyimpulkan bahwa ada pengaruh signifikan antara skor perolehan tes kosakata pada kelompok eksperimen dan kontrol $(\mathrm{p}=0,000<0,05)$, dan signifikan pada skor perolehan tes psikomotor $(\mathrm{p}=0,016>0,05)$.

Berdasarkan uraian di atas, dapat disimpulkan bahwa ada pengaruh signifikan penerapan metode snowball throwing terhadap penguasaan kosakata dan kemampuan psikomotorik. Dengan demikian, snowball throwing dapat digunakan sebagai metode untuk meningkatkan kemampuan kosakata Bahasa Inggris siswa serta kemampuan psikomotor, namun metode tersebut hanya dapat meningkatkan kemampuan psikomotor dalam taraf yang rendah dan tidak begitu pesat dibandingkan pada penguasaan kosakata.

Kemampuan psikomotorik adalah suatu kemampuan yang bersifat kompleks sehingga membutuhkan waktu yang relatif lebih lama dan frekuensi pengembangan yang cenderung lebih besar dari 3 sesi pertemuan/ eksperimen. Pengembangan kemampuan psikomotor juga dapat dilakukan dengan penerapan metode lain yang lebih sesuai atau bahkan penggabungan kedua metode berbeda untuk dapat meningkatkan kemampuan psikomotorik siswa.

Meninjau hasil uji 2 sampel berpasangan terlihat bahwa ada nilai signifikansi penguasaan kosakata $(\mathrm{p}=0,000)$ dan psikomotor $(\mathrm{p}=0,016)$ pada kelompok eksperimen lebih rendah dari batas kritis penelitian 0,05 , sehingga dapat disimpulkan ada perbedaan bermakna antara skor pretest dan posttest pada penguasaan kosakata dan psikomotor (H1 diterima). Hal sebaliknya pada kelompok kontrol terlihat tidak ada perbedaan bermakna antara skor pretest dan posttest pada penguasaan kosakata $(\mathrm{p}=0,081)$ dan psikomotor $(\mathrm{p}=0,090)$. Berikut adalah grafik perubahan skor pada variabel ukur penguasaan kosakata siswa.

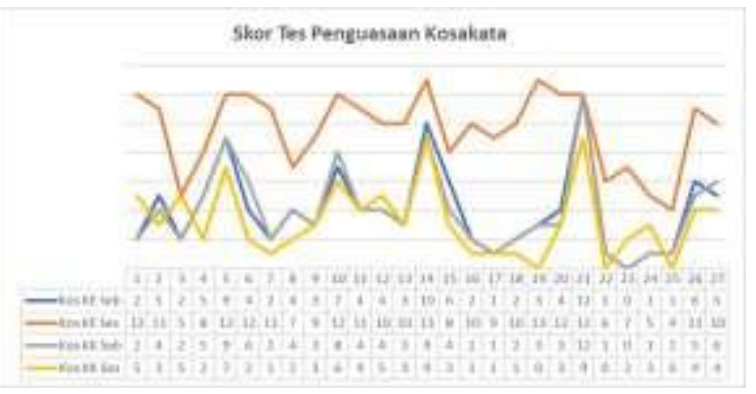

\section{Gambar 1. Skor Tes Penguasaan Kosakata}

Berbeda dengan kemampuan kosakata Bahasa Inggris yang dapat ditingkatkan melalui penerapan metode snowball throwing, kemampuan psikomotorik siswa dapat ditingkatkan melalui metode tersebut meskipun cenderung rendah. Meskipun pada hasil uji hipotesis terjadi peningkatan rata-rata peringkat pada kemampuan kosakata Bahasa Inggris dan psikomotorik siswa dan kemampuan psikomotorik secara signifikan. Berikut adalah grafik perubahan skor pada variabel ukur kemampuan psikomotor siswa.

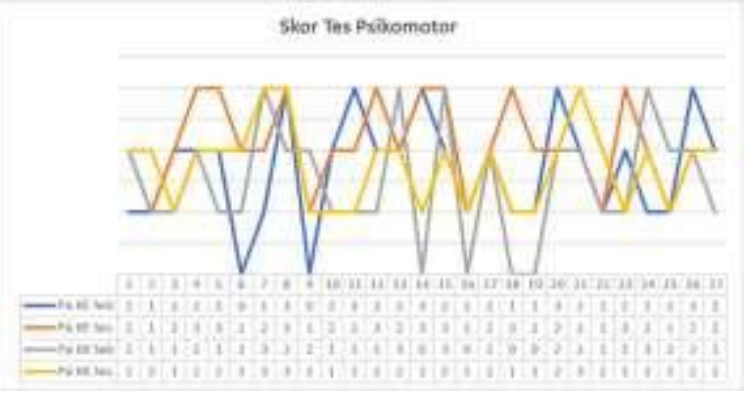

Gambar 2. Skor Tes Psikomotor

Dengan demikian penerapan metode snowball throwing dapat meningkatkan penguasaan kosakata dan kemampuan psikomotorik siswa SD Islam Terpadu Kota Sorong. Salah satu poin yang melatarbelakangi peningkatan kemampuan psikomotor meskipun signifikan namun cenderung rendah, hal tersebut adalah terbatasnya waktu penelitian dan kurangnya simulasi permainan. Dengan 
kata lain kemampuan psikomotorik tidak dapat diubah atau ditingkatkan dalam waktu singkat, dibutuhkan waktu lebih lama untuk melatih motorik siswa. Disisi lain, jumlah subjek yang sedikit juga membuat data tidak terdistribusi secara normal. Sebagaimana yang telah dijelaskan sebelumnya bahwa jumlah total siswa kelas 1 SD Islam Terpadu Kota Sorong adalah 54 siswa dan hanya terdiri dari dua kelas yaitu IA dan IB dengan jumah siswa perkelas sebanyak 27 orang. Hal ini membuat peneliti tidak memiliki pilihan lain selain menggunakan seluruh subjek yang ada.

\section{Kesimpulan}

Berdasarkan analisis data yang telah diuraikan pada bab sebelumnya, dapat disimpulkan bahwa penerapan metode snowball throwing dalam pembelajaran bahasa inggris memiliki pengaruh untuk meningkatkan penguasaan kosakata dan kemampuan psikomotorik siswa SD Islam Terpadu Kota Sorong. Meninjau hasil uji 2 sampel berpasangan terlihat bahwa ada nilai signifikansi penguasaan kosakata $(\mathrm{p}=0,000)$ dan psikomotor $(\mathrm{p}=0,016)$ pada kelompok eksperimen lebih rendah dari batas kritis penelitian 0,05 , sehingga dapat disimpulkan ada perbedaan bermakna antara skor pretest dan posttest pada penguasaan kosakata dan psikomotor $\left(\mathrm{H}_{1}\right.$ diterima). Pada kelompok kontrol terlihat tidak ada perbedaan bermakna antara skor pretest dan posttest pada penguasaan kosakata $(\mathrm{p}=0,081)$ dan psikomotor $(\mathrm{p}=0,090)$.

Dengan demikian, dapat terlihat bahwa perbandingan skor pretest dan posttest perolehan pengukuran penguasaan kosakata dan psikomotorik pada kelompok eksperimen berbeda signifikan dibandingkan dengan kelompok kontrol. Sedangkan berdasarkan uji sampel berpasangan terlihat bahwa terjadi peningkatan skor yang signifikan pada kelompok eksperimen sebelum dan sesudah diberikan perlakuan berupa metode snowball throwing. Hasil analisis data penelitian menunjukkan bahwa hipotesis satu dalam penelitian ini diterima dan hipotesis nihil ditolak.

\section{Daftar Pustaka}

Alderson, J.C. \& Bachman, L. F. (2000). Assesssing Vocabulary. Cambridge Language Assessment. Cambridge University Press.

Bandura, A. 1986. Social Foundation of Thought and Action: A Social Cognitive Theory. New York: Prentice Hall.

Berger, L. M., \& McLanahan, S. S. (2015). Income, relationship quality, and parenting: Associations with child development in two- parent families. Journal of Marriage and Family, 77(4), 9961015.

Bloom, B., Englehart, Furst, Hill, dan Krathwohl. 1956. Taxonomy of Educational Objectives: $\quad$ The Classification of Educational Goals. Handbook I: Cognitive domain. New York: Longmans Green.

Burns, A., Freeman, D., \& Edwards, E. (2015). Theorizing and studying the language- teaching mind: Mapping research on language teacher cognition. The Modern Language Journal, 99(3), 585601.

Coady, J. and Huckin, T. (1997). Second Language Vocabulary Acquisition. Cambridge: Cambridge University Press.

Depdiknas. 2003. Undang-Undang RI Nomor 20 Tahun 2003 Pasal 40 Ayat 2, tentang Sistem Pendidikan Nasional.

Duff, D., Tomblin, J. B., \& Catts, H. (2015). The influence of reading on vocabulary growth: A case for a Matthew effect. Journal of Speech, Language, and Hearing Research, 58(3), 853-864.

Fox, J.V.D. 2012. The Self-Actualizing Teacher. Improving College and University Teaching Journal. 13(3): 147-148.

Gilman, L. 2012. The Theory of Multiple Intelligences. Indiana: Indiana University.

Harun Rasyid. (2009). Assesmen Perkembangan Anak Usia Dini. Yogyakarta: Multipresindo.

Hiebert, E. H. And Kamil, M. L. (2005). Teaching and Learning Vocabulary: Bringing Research to Practice. Lawrence Erlbaum Associates Publisher: London. 
Khanifatul. (2014). Pembelajaran Inovatif: Strategi Mengelola Kelas Secara Efektif dan Menyenangkan. Yogyakarta: ArRuzz Media.

Kwan, Y. W., \& Wong, A. F. (2015). Effects of the constructivist learning environment on students' critical thinking ability: Cognitive and motivational variables as mediators. International Journal of Educational Research, 70, 68-79.

LeBarton, E. S., Goldin-Meadow, S., \& Raudenbush, S. (2015). Experimentally induced increases in early gesture lead to increases in spoken vocabulary. Journal of Cognition and Development, 16(2), 199-220.

Masek, A., \& Masduki, M. (2017). Participation of Shy Children during the Teaching and Learning of Basic Psychomotor Skill. Pertanika Journal of Social Sciences \& Humanities.

Maslow, A.H. 1998. Toward a Psychology of Being ( $3^{\text {rd }}$ Edition). New Jersey: Willey and Sons.

McCarten, J. (2007). Teaching Vocabulary. New York: Cambridg Universiti Press.

Padmanabha, C. (2018). Critical Thinking: Conceptual Framework. Journal on Educational Psychology, 11(4).

Pane, I., \& Ernidawati, T. (2014). Improving The Students' Speaking Achievement in Narrative Text Through Snowball Throwing Model. GENRE Journal of Applied Linguistics of FBS Unimed, 3(1).

Paul Suparno. (2001). Teori Perkembangan Kognitif Jean Piaget. Yogyakarta: Kanisiun.

Sari, S. A., Jasmidi, J., Kembaren, A., \& Sudrajat, A. (2018). The Impacts of ChemopolyEdutainment to Learning Activities and Responses. Journal of Education and Learning, 12(2), 311-318.

Sumantri. (2005). Metode Keterampilan Motorik Anak Usia Dini. Jakarta: Diknas.

Scott, W. A. and Ytreberg, E. H. (2002). Teaching English to Children. Longman Ldt.

Shadish, Cook, dan Campbell. 2002. Experimental and Quasi-Experimental Design for Generalized Causal Inference. Boston: Houghton Mifflin Company.

Smith, Mark K. (2002). Howard Gardner, multiple intelligences and education. In The encyclopedia of informal education. Boston: Harvard University Press.

Stein, M.I. 2014. Stimulating Creativity: Individual Procedures. London: Academic Press Inc. Ltd.

Susanty, H. (2016). Use of the Snowball Throwing Technique for Teaching Better ESL Speaking. English Education Journal, 7(1), 117-129.

Wheatley, K.F. 2005. The Case for Reconceptualizing Teacher Efficacy Research. Teaching and Teacher Education. 21: 747-766.

Woolfolk, A., dan Davis. 2005. Teachers' Sense of Efficacy and Adolescent Achievement. In T. Urdan \& F. Pajares (Eds.). Adolescence and Education. 5: 117-137. Greenwich, $\quad$ CT: Information Age.

Wright, A., Betteridge, A. \& Buckby, M. (2006). Games for Language Learning. New York: Cambridge Universiti Press. 